\title{
Factors Responsible for Students' Unrest in Nigerian Tertiary Institutions: Implications for Counselling Practices
}

\begin{abstract}
This study, thus, investigated the factors responsible for students' unrest in Nigerian Tertiary Institutions. Further investigation was also done based on moderating variables of age, gender, and religion if they would have any bearing on the participants'views. The study was descriptive in nature. The sample consisted of one thousand and two hundred undergraduates, who were selected in six Universities in Nigeria using purposive, simple random, and systematic random techniques. A new questionnaire labelled FRSUQ (Factors Responsible for Students' Unrest Questionnaire) was developed and used to collect data. The results showed that the factors responsible for students' unrest in Nigerian Tertiary Institutions are unfavorable Government policies; poor staffstudents' relationship; poor teaching-learning facilities; high tuition fees; and non-responsiveness of University authorities among others. Results also showed that there were no significant differences in the factors responsible for students' unrest in Nigerian Universities based on age, gender, and religion.
\end{abstract}

KEY WORD: Factors Responsible for; Students' Unrest; Nigerian Tertiary Institutions; Counsellors.

ABSTRAKSI: "Faktor-faktor yang Bertanggung Jawab atas Keresahan Mahasiswa di Lembaga Pendidikan Tinggi Nigeria: Implikasi bagi Praktek Konseling". Penelitian ini, dengan demikian, menyelidiki faktor-faktor yang bertanggung jawab atas keresahan mahasiswa di Lembaga Pendidikan Tinggi Nigeria. Penyelidikan lebih lanjut juga dilakukan berdasarkan variabel moderasi usia, jenis kelamin, dan agama jika mereka memiliki pandangan yang berbeda terhadap peserta. Penelitian ini bersifat deskriptif. Sampel terdiri dari seribu dua ratus mahasiswa, yang dipilih di enam Universitas di Nigeria menggunakan teknik sampel acak bertujuan, sederhana, dan sistematis. Kuesioner baru berlabel FRSUQ (Kuesioner Faktor-faktor yang Bertanggung Jawab atas Keresahan Mahasiswa) dikembangkan dan digunakan untuk mengumpulkan data. Hasil penelitian menunjukkan bahwa faktor-faktor yang bertanggung jawab atas keresahan mahasiswa di Lembaga Pendidikan Tinggi Nigeria adalah kebijakan Pemerintah yang tidak menguntungkan; hubungan staf-mahasiswa yang lemah; fasilitas belajar-mengajar yang buruk; biaya kuliah yang tinggi; serta tidak responsifnya pihak otoritas Universitas antara lain. Hasil kajian juga menunjukkan bahwa tidak ada perbedaan signifikan dalam faktor-faktor yang bertanggung jawab atas keresahan mahasiswa di Universitas Nigeria berdasarkan usia, jenis kelamin, dan agama.

KATA KUNCI: Faktor-faktor yang Bertanggung Jawab atas; Keresahan Mahasiswa; Lembaga Pendidikan Tinggi Nigeria; Pembimbing.

About the Author: Dr. Aminat Adeola Odebode is a Lecturer at the Department of Counsellor Education UNILORIN (University of Ilorin), Nigeria. For academic interests, the Author is able to be contacted via e-mail adrress at: odebode.aa@, unilorin.edu.ng

Suggested Citation: Odebode, Aminat Adeola. (2019). "Factors Responsible for Students' Unrest in Nigerian Tertiary Institutions: Implications for Counselling Practices" in MIMBAR PENDIDIKAN: Jurnal Indonesia untuk Kajian Pendidikan, Volume 4(2), September, pp.93-102. Bandung, Indonesia: UPI [Indonesia University of Education] Press, ISSN 2527-3868 (print) and 2503-457X (online).

Article Timeline: Accepted (July 3, 2019); Revised (August 17, 2019); and Published (September 30, 2019). 


\section{INTRODUCTION}

Tertiary Educational Institutions in Nigeria are established to give its students sound education, to be able to function appropriately in any situation, to be productive, attain self-actualization, and be self-fulfilled (Ajibade, 2014). To realize all these goals, the NPE (National Policy on Education), in 2010, has its policy to: (1) the acquisition, development, and inculcation of the proper value-orientation for the survival of the individual and society; (2) the development of the intellectual capacities of individuals to understand and appreciate their environment; (3) the acquisition of both physical and intellectual skills, which will enable individuals to develop into useful members of the community; and (4) the acquisition of an objective view of the local and external environments ( $c f$ FGN, 2009; David, 2010; and NPE, 2010).

It is expected that these goals are met through: teaching and learning of skills; carrying out research to discover knowledge; dissemination of existing and current information; and rendering community service and training professionals for the development of intermediate and high-level manpower (Yusuf, 2017). These goals are key to national development. However, research by scholars, such as B.M. Taiwo (2012); D. Ajibade (2014); and K.U. Davies, G.E. Ekwere \& U.U. Uyanga (2015), have shown that many Nigerian Tertiary Institutions are finding it difficult to attain the expected goals, due to many challenges facing them (Taiwo, 2012; Ajibade, 2014; and Davies, Ekwere \& Uyanga, 2015). One of those challenges is students' unrest (Adeyemi, 2009; Etadon, 2013; Ajibade, 2014; and Davies, Ekwere \& Uyanga, 2015).

Students' unrest in the institutions of higher learning is prevalent in recent years. This unrest occurs in the form of riot demonstration, protest, boycotts, harassment, strike and burning of properties, and killing (Mjema, 2013). Today, students' unrest has been identified as one of the most visible perpetual challenges of significance in Nigerian educational institutions. Worse still, one can rightly predict that students of tertiary educational institutions will riot in any academic session. Students' unrest has, however, lead to continuous closure of schools, which adversely affect the coverage of the curriculum in each academic session (Davies, Ekwere \& Uyanga, 2015). ${ }^{1}$

An observation of the Nigerian universities shows that many factors underpin student unrest' in recent times. These factors include students' not taking part in decision-making processes in the university. Accordingly, the degree of students' involvement in the decisionmaking processes has been noted to be indirectly related to the rate of student unrest. Hence, when students are more involved in decision making, the frequency of unrest will probably reduce (Omonijo, 2013; Oni \& Adetoro, 2015; and Oluwasanmi, Akande \& Taiwo, 2016).

A theoretical framework that this study can be hinged on is the Theory of Relative Deprivation. The theory states that people have needs that they strive to meet. When there is a loophole between what people want and what they get in reality, relative deprivation begins to play (Davies, Ekwere \& Uyanga, 2015). The theorists also stated that when individuals' condition improves, there was higher expectations which in turn lead to frustration, when those expectations are not met. This means that the higher the expectation, the higher the deprivation and frustration emerge ( $c f$ Dzuverovic, 2013; Saleh, 2013; and Davies, Ekwere \& Uyanga, 2015).

The theorists also believed that even though there are downturn changes in the economic condition, which is capable of leading to riot, riot is often caused by the

${ }^{1}$ See also, for example, "Curbing Campus Vices" in The Nation [newspaper]. Nigeria: 28 th August 2014. 
perception of the low economic condition. The self is, therefore, prone to reacting towards frustration in the environment to get over deprivation, anxiety, pain, and frustration. A careful look at fresh students of tertiary institutions in Nigeria will reflect that many of them have high expectations as to what the University holds for them. Due to high expectations, many of their preconceived ideas do not materials. Frustration, however, sets in which lead to unrest to wade off pain and deprivations (Dzuverovic, 2013; Saleh, 2013; Greenberg, 2014; Davies, Ekwere \& Uyanga, 2015; and Bhui et al., 2016).

Statement of the Problem. It is disheartening that hardly in any tertiary institution in Nigeria that students will not protest. This unrest has cost the nation, institutions, students, and the society at large irreparable losses, such as vandalization of properties; waste of time and energy; fear among students and non-students; and lifelong injury and even death. Although many researchers have been conducted in the past, which includes but not limited to that of T.O. Adeyemi (2009), and other scholars, who researched on causes, consequences, and control of student's crises in public and private universities in Nigeria (Adeyemi, 2009; Akeusola, Viatonu \& Asikhia, 2012; and Orunbon et al., 2018).

E.E. Chukwuemeka \& V.N.O. Agbara (2010) studied Niger Delta youth restiveness and socio-economic development of Nigeria. Also, B.M. Taiwo (2012) studied students' unrest in Nigerian tertiary institutions: age and sex as determinants. Unfortunately, students' unrest is still the order of the day in Nigerian tertiary institutions. It is based on this reason that this study, further, explored the factors responsible for students' unrest in Nigerian tertiary institutions ( $c f$ Aluede et al., 2005; Chukwuemeka \& Agbara, 2010; Taiwo, 2012; Davies, Ekwere \& Uyanga, 2015; and Fayankinnu, 2015).
Based on the purpose of this study, a research question was raised, thus: "What are the factors responsible for students' unrest in Nigerian tertiary institutions?".

Research Hypotheses. The research hypotheses are able to be stated as following here: (1) There is no significant difference in the factors responsible for students' unrest in Nigerian tertiary institutions based on age, gender, and religion; (2) There is no significant difference in the factors responsible for students' unrest in Nigerian tertiary institutions based on gender; and (3) There is no significant difference in the factors responsible for students' unrest in Nigerian tertiary institutions based on religion.

\section{METHODS}

A study of this nature was set out to describe the factors that cause students' unrest in universities in Nigeria; thus, the descriptive survey method of research design was considered suitable. It is a research method that allows the researcher to explain vividly, events, and ideas surrounding a phenomenon. Similarly, the descriptive survey research method allows room for generalization of the entire population in which sample was drawn. It is in view of these that the researchers considered the descriptive method as appropriate for this study (Williams, 2007; Polit \& Beck, 2010; and Sileyew, 2019).

The population for this study consisted of all undergraduates students in Nigerian universities. However, the target population comprised undergraduates in selected Federal Universities in Nigeria. There are six geopolitical zones in Nigeria; in each geopolitical zone, a State was purposively chosen due to the likely occurrence of students' unrest. The States chosen were Cross-River, Lagos, Abia, Plateau, Borno, and Kano. In each of these States, a Federal University was again purposively chosen.

In the Universities, four Faculties were 
Table 1:

Mean and Rank Order on the Factors Responsible for Students Unrest in Nigerian Tertiary Institutions

\begin{tabular}{clcc}
\hline Item No. & In my opinion, factors responsible for students' unrest are: & Mean & Rank Order \\
\hline 5 & Unfavorable government policies. & 3.81 & $1^{\text {st }}$ \\
1 & Poor staff-students' relationship. & 3.80 & $2^{\text {nd }}$ \\
2 & Poor teaching-learning facilities. & 3.76 & $3^{\text {rd }}$ \\
3 & High tuition fee. & 3.74 & $4^{\text {th }}$ \\
6 & Poor students' welfare. & 3.70 & $5^{\text {th }}$ \\
12 & Unsupportive students' unionism. & 3.67 & $6^{\text {th }}$ \\
7 & Non-responsiveness of school authority. & 3.65 & $7^{\text {th }}$ \\
11 & National issues e.g. fuel scarcity. & 3.60 & $8^{\text {th }}$ \\
10 & Uncooperativeness of the community. & 3.62 & $9^{\text {th }}$ \\
9 & Cultism on campus. & 3.61 & $10^{\text {th }}$ \\
8 & Non-availability of basic amenities e.g. water supply. & 3.60 & $11^{\text {th }}$ \\
4 & Low-commitment of students towards schooling. & 3.54 & $12^{\text {th }}$ \\
\hline
\end{tabular}

randomly chosen using simple random sampling procedure; in the Faculties, the systematic random sampling technique was adopted to select fifty respondents. This made a total of 200 undergraduate students that were selected in each University. In all, a total of 1,200 students of tertiary institutions in Nigeria were chosen to participate in the study.

The instrument titled "FRSUQ (Factors Responsible for Students' Unrest Questionnaire)" was developed and used to collect data to address the research question and hypotheses. FRSUQ contained 12 items that sought information on the factors Responsible for Students' Unrest in Nigerian Tertiary Institutions. The validity of FRSUQ was conducted by giving the instruments to team of experts in the Universities of Ilorin, Nigeria. These experts corrected and made suggestions that improved on the instrument; they affirmed that the instrument had face and content validity ( $c f$ Okwakpam \& Okwakpam, 2012; Davies, Ekwere \& Uyanga, 2015; and Dutt, Chen \& Nair, 2016).

The reliability of the questionnaire was determined through a test re-test reliability. This was affirmed by administering the instrument on 20 students of a tertiary institution in Ogbomoso, Oyo State, twice at an interval of 3 weeks. These students have similar characteristics as the respondents of this study, but they did not partake in the study. The two sets of score were correlated using Pearson's Moment Correlation formula and a reliability co-efficient of .81 was gotten; this affirmed that the instrument was reliable for the study (Bolarinwa, 2015; Chiwaridzo et al., 2017; and Lee, Yim \& Kim, 2018).

The mean score for taking decision is 2.5; therefore, any item with mean score 2.5 and above was adjudged the factors responsible for students' unrest in Nigerian tertiary institutions. The data and hypotheses were analysed and tested using frequency counts and percentages, means, t-test, and ANOVA (Analysis of Variance) at 0.05 alpha level (Garth, 2008; Greenland et al. 2016; and Marshall, 2017).

\section{RESULTS AND DISCUSSION}

Results. The data were analysed using frequency counts and percentages, means, t-test, and ANOVA (Analysis of Variance). See table 1.

Since all the items on the tables have mean scores above 2.5 , which is the bench mark for making decision for the factors responsible for students' unrest in 
Table 2:

Mean, Standard Deviation, ANOVA, and t-value on the Factors Responsible for Students' Unrest in Nigerian Tertiary Institutions Based on Gender Age and Religion $(\mathrm{N}=1200)$

\begin{tabular}{llllcll}
\hline Gender: & N & Mean & SD & df & Cal. T-value & Crit. T-value Decision \\
\hline Female & 552 & 57.18 & 13.53 & 1198 & 1.03 & 1.96 Not rejected \\
Male & 648 & 64.01 & 18.06 & & & \\
\hline Source & df & SS & Mean Squares & Cal. F-value & Crit. F-value \\
\hline Age: & & & & & \\
Between Groups & 2 & 2345.250 & 1172.625 & 1.91 & 3.00 Not rejected \\
$\begin{array}{l}\text { Within Groups } \\
\text { Total }\end{array}$ & 1197 & 734559.399 & 613.667 & & \\
\hline Source & 1199 & 736904.649 & & & \\
\hline Religion: & df & SS & & Mean Squares & Cal. F-value & Crit. F-value \\
Between Groups & 2 & 2491.210 & 1245.605 & 2.03 & 3.00 Not rejected \\
Within Groups & 1197 & 734056.659 & 613.247 & & \\
Total & 1199 & 736547.779 & & & & \\
\hline
\end{tabular}

Nigerian tertiary institutions in this study. Therefore, it can be concluded that the factors responsible for students' unrest are: Unfavorable government policies; Poor staff-students' relationship; Poor teachinglearning facilities; High tuition fees; nonresponsiveness of school authority among others. See, then, the table 2.

Table 2 shows the t-value and ANOVA (Analysis of Variance) value of factors responsible for students' unrest in Nigerian tertiary institutions. On the table, the t-value of 1.03 is less than the critical t-value of 1.96. Therefore, the hypothesis based on gender is not rejected. The table also shows that for age, the critical F-value of 1.91 is less than the critical F-value of 3.00. Therefore, the hypothesis based on age is not rejected. Similarly, the table also shows that for religion, the critical F-value of 2.03 is less than the critical F-value of 3.00. Therefore, the hypothesis based on religion is not rejected.

Discussion. The findings of this study revealed that the factors responsible for students' unrest are: Unfavourable government policies; Poor staff-students' relationship; Poor teaching-learning facilities; High tuition fees; and Nonresponsiveness of university authorities among others. This finding is consistent with that of O. Akeusola, O. Viatonu \& O.A. Asikhia (2012) and Mashauri Mwangasha Mjema (2013), who found that the factors responsible for students' unrest are: unfavourable government policies; poor staff-students' relationship; and poor teaching-learning (Akeusola, Viatonu \& Asikhia, 2012; and Mjema, 2013).

The shortage of funds been allotted to Nigerian tertiary institutions has been responsible for high tuitions, moribund library, social and laboratory facilities, which result to students' unrests in most tertiary educational institutions in the country. In this context, H.T. Ekundayo \& I.A. Ajayi (2009) and O. Akeusola, O. Viatonu \& O.A. Asikhia (2012) noted that the Nigerian government over the years has not met the UNESCO (United Nations Educational, Scientific, and Cultural Organization) recommendation of $26 \%$ of the total budget allocation to education sector (Ekundayo \& Ajayi, 2009; and Akeusola, Viatonu \& Asikhia, 2012).

Similarly, the finding of this study corroborates that of H.T. Ekundayo \& H.O. Alonge (2010), and other scholars, that found that students' unrest in Nigerian universities occurs, due to extreme rules 
and regulation; non-provision of basic amenities; and prominent level of students' involvement in cult activities on campus (cf Adeyemi, Ekundayo \& Alonge, 2010; Ekundayo \& Alonge, 2010; and Odu, 2013).

Hypothesis one which stated that "there is no significant difference in the factors responsible for students' unrest in Nigerian tertiary institutions based on gender" was not rejected. This implies that whether the respondents are male or female, does not affect the expression of factors responsible for students' unrest. It also means that both male and female respondents have the same expression about the factors responsible for students' unrest.

This finding validates the findings of B.M. Taiwo (2012); F.I. Etadon (2013); Onyike Margaret Odu (2013); and other scholars, who found that gender had no significant difference in the expression of factors responsible for students' unrest in Nigerian tertiary institutions. This finding could be that students irrespective of gender have needs and like the human need theory explained, they would strive to have their needs met (Taiwo, 2012; Etadon, 2013; Odu, 2013; Olibie, Eziuzo \& Enueme, 2013; and Bulut, 2018).

Hypothesis two which stated that "there is no significant difference in the factors responsible for students' unrest in Nigerian tertiary institutions based on age" was not rejected. This implies that all respondents regardless of their ages did not have different expressions on the factors responsible for students' unrest.

This finding tally with that of B.M. Taiwo (2012); K.U. Davies, G.E. Ekwere \& U.U. Uyanga (2015); and other scholars, who found that age does not affect the expression of factors responsible for students' unrest in Nigerian tertiary institutions. The reason for this finding could be that even though the respondents were of varied ages, they are all students and they have the same experience about the issues causing unrest (Adeyemi, 2009; David, 2010; Taiwo, 2012; Davies, Ekwere \& Uyanga, 2015; and Fayankinnu, 2015).

Hypothesis three which stated that "there is no significant difference in the factors responsible for students' unrest in Nigerian tertiary institutions based on religion" was not rejected. This means that the religious belief of the respondents does not come to play in the expression of factors responsible for students' unrest in Nigerian tertiary institutions.

This finding supports the finding of T.O. Adeyemi (2009); Mashauri Mwangasha Mjema (2013); and other scholars, who found that religion has no significant difference in the factors responsible for students' unrest in Nigerian tertiary institutions. This finding could be that despite the respondents do not share the same religious faith, they are all students of Nigerian tertiary institutions and could all express the issues that could lead to students' unrest (Adeyemi, 2009; David, 2010; Mjema, 2013; Fayankinnu, 2015; and Sulaiman, 2016).

\section{CONCLUSION}

The factors responsible for students' unrest in Nigerian tertiary institutions are: Unfavourable government policies; Poor staff-students' relationship; Poor teachinglearning facilities; High tuition fees; and Non-responsiveness of university authorities among others. No significant difference existed in the factors responsible for students' unrest in Nigerian tertiary institutions based on age, gender, and religion.

Implications of the findings for counselling practices are: the finding of this study implies that counsellors should persuade Nigerian government to adequately fund education sector. This will help Nigerian tertiary institutions to acquire updated teaching-learning facilities and put in place sufficient infrastructural facilities. Similarly, counsellors should also encourage 
Nigerian government to make favourable policies, such as to reduce high school tuition fees and not the policies that harsh and capable of pushing students towards crisis.

Provision of infrastructural facilities, teaching-learning, and university authorities should be counselled to be responsive to request or complaint of students. When students give complaints and the school authority is indifferent about it could promote anger and frustration in the students. Counsellors should organize continuous seminars for lecturers to facilitate friendly staff-student's relationship. Skills of tolerance and human relationship should be widely taught to both staff and students to promote peaceful coexistence in tertiary institutions.

Students should be counselled to say "No to Violence". This can be done for fresh students during orientation programmes. Other students could be taught conflict resolution skills to resolve issues without necessarily fighting. Security agencies in the country should also be educated and encouraged to help keep cultism in tertiary institutions at bay as it has been noted that the existence of cultism in Nigerian tertiary institutions is one of the factors responsible for students' unrest. Lastly, counsellors should strive to be peace advocates between students, university authorities, Nigerian government, and the Nigerian society at large. ${ }^{2}$

\section{References}

Adeyemi, T.O. (2009). "Causes, Consequences, and Control of Student's Crises in Public and Private Universities in Nigeria" in Academic Journals of

${ }^{2}$ Statement: $\mathrm{I}$, hereby, declare that this article is my original academic work, and it is not the result of plagiarism. All the sources cited in the analysis and discussion, I include clearly and completely in the Reference list. This article has also not been submitted, reviewed, and published by other scientific journals. I am willing to be academically sanctioned, if what I declare turns out to be, later on, it is not true.
Educational Research and Review, Volume 4(4), pp.156-163.

Adeyemi, T.O., H.T. Ekundayo \& H.O. Alonge. (2010). "Managing Students' Crisis in Tertiary Institutions in Nigeria" in Journal of Research in National Development, Volume 8, pp.14-21.

Ajibade, D. (2014). "Students' Crisis in Nigerian Tertiary Institutions: A Review of the Causes and Management Style" in KHAZAR: Journal of Humanities and Social Sciences, Volume 2, pp.56-76.

Akeusola, O., O. Viatonu \& O.A. Asikhia. (2012). "Perceived Causes and Control of Student's Crises in Higher Institutions in Lagos State, Nigeria" in Journal of Education and Practice, Volume 3(10), pp.29-43.

Aluede, Oyaziwo et al. (2005). "Student Unrest in Nigerian Universities: Looking Back and Forward" in Journal of Social Sciences, Vol.10, Iss.1, pp.17-22. Available online also at: https:// www.tandfonline.com/doi/abs/10.1080/09718923. 2005.11892454 [accessed in Ilorin, Nigeria: $1^{\text {st }}$ June 2018].

Bhui, Kamaldeep et al. (2016). "Perceptions of Work Stress Causes and Effective Interventions in Employees Working in Public, Private, and Non-Governmental Organisations: A Qualitative Study" in BJPsych Bulletin, Volume 40(6), pp.318-325. Available online also at: https:/www. ncbi.nlm.nih.gov/pmc/articles/PMC5353523/ [accessed in Ilorin, Nigeria: $1^{\text {st }}$ June 2018].

Bolarinwa, O.K. (2015). "Principles and Methods of Validity and Reliability Testing of Questionnaires Used in Social and Health Science Researches" in Nigerian Postgraduate Medical Journal, Vol.22, Iss.4, pp.195-201. Available online also at: http:// www.npmj.org/article.asp?issn=1117-1936;year= 2015; volume $=22 ;$ issue $=4$; spage $=195$; page $=201$; aulast $=$ Bolarinwa [accessed in Ilorin, Nigeria: $9^{\text {th }}$ June 2018].

Bulut, Safiye Sarici. (2018). "Obstacles to Selfactualization of College Students: The Case of Gazi Faculty of Education" in Universal Journal of Educational Research, Volume 6(10), pp.22712279. Available online also at: http://www.hrpub. org/download/20180930/UJER26-19511875.pdf [accessed in Ilorin, Nigeria: $15^{\text {th }}$ January 2019].

Chiwaridzo, Matthew et al. (2017). "Content Validity and Test-Retest Reliability of a Low Back Pain Questionnaire in Zimbabwean Adolescents" in Archives of Physiotherapy, Volume 7(3), pp.1-12. Available online also at: https:// archivesphysiotherapy.biomedcentral.com/track/ pdf/10.1186/s40945-017-0031-y [accessed in Ilorin, Nigeria: $9^{\text {th }}$ June 2018 .

Chukwuemeka, E.E. \& V.N.O. Agbara. (2010). 
"Niger Delta Youth Restiveness and SocioEconomic Development of Nigeria" in Educational Research and Reviews, Volume 5(7), pp.400-407.

"Curbing Campus Vices" in The Nation [newspaper]. Nigeria: $28^{\text {th }}$ August 2014.

David, Ajibade. (2010). "Students' Crisis in Nigerian Tertiary Educational Institutions: A Review of the Causes and Management Style" in Khazar Journal of Humanities and Social Sciences, pp.56-76. Available online also at: http://jhss-khazar.org/wp-content/ uploads/2010/04/05pdfMANAGEMENT-OFSTUDENT-5-1-1.pdf [accessed in Ilorin, Nigeria: $25^{\text {th }}$ May 2018].

Davies, K.U., G.E. Ekwere \& U.U. Uyanga. (2015). "Factors Influencing Students Unrest in Institutions of Higher Learning and its Implications on the Academic Performance of Students in University of Uyo, Akwa Ibom State, Nigeria" in Original Scientific Paper. DOI: 10.17810/2015.21. Available and owned by the Author.

Dutt, A.S., I. Chen \& R. Nair. (2016). "Reliability and Validity of Skills and Needs Inventories in Functional Behavior Assessments and Interventions for School Personnel" in Journal of Special Education, Volume 49(4), pp.232-242.

Dzuverovic, Nemanja. (2013). “Does More (or Less) Lead to Violence? Application of the Relative Deprivation Hypothesis on Economic InequalityInduced Conflicts" in CIRR, Volume XIX (68), pp.115-132.

Ekundayo, H.T.\& I.A. Ajayi. (2009). “Towards Effective Management of University Education in Nigeria" in International NGO Journal, Volume 4(8), August, pp.342-347. Available online also at: https://academicjournals.org/article/ article1381500283 Ekundayo\%20and\%20Ajayi. pdf [accessed in Ilorin, Nigeria: $15^{\text {th }}$ June 2018].

Ekundayo, H.T. \& H.O. Alonge. (2010). "Managing Students' Crisis in Tertiary Institutions in Nigeria" in Journal of Research National Development, Volume 8(1), pp.71-90.

Etadon, F.I. (2013). "Campus Conflict Involving Students and University Management in Nigeria: A Case Study of the University of Ibadan" in International Journal of Education Science, Volume 5(3), pp.333-343.

Fayankinnu, Emmanuel Abiodun. (2015). "Student Unrest in a Nigerian Tertiary Institution: Exploring a Gender-Specific Action" in QUESTIA: Trusted Online Research. Available online also at: https://www.questia.com/library/ journal/1P3-3913535381/student-unrest-in-anigerian-tertiary-institution [accessed in Ilorin, Nigeria: $1^{\text {st }}$ June 2018].
FGN [Federal Government of Nigeria]. (2009). "Federal Republic of Nigeria" in Official Gazette, Vol.96, No.2.

Garth, Andrew. (2008). "Analysing Data Using SPSS: A Practical Guide for those Unfortunate Enough to Have to Actually Do it". Available online at: https://students.shu.ac.uk/lits/it/ documents/pdf/analysing data using_spss.pdf [accessed in Ilorin, Nigeria: $9^{\text {th }}$ June 2018].

Greenberg, Melanie. (2014). "Feeling Deprived Can Lead to Some Illogical Behavior: 5 Ways to Overcome a Misguided Mindset" in Psychology Today, on January 16. Available online also at: https://www.psychologytoday.com/intl/blog/themindful-self-express/201401/feeling-deprivedcan-lead-some-illogical-behavior [accessed in Ilorin, Nigeria: $1^{\text {st }}$ June 2018].

Greenland, Sander et al. (2016). "Statistical Tests, $P$ Values, Confidence Intervals, and Power: A Guide to Misinterpretations" in European Journal of Epidemiology, Volume 31, pp.337-350. Available online also at: https:/www.ncbi.nlm. nih.gov/pmc/articles/PMC4877414/ [accessed in Ilorin, Nigeria: $9^{\text {th }}$ June 2018].

Lee, J., M.H. Yim \& J.Y. Kim. (2018). "TestRetest Reliability of the Questionnaire in the Sasang Constitutional Analysis Tool (SCAT)" in Integrative Medicine Research, Vol.7, Iss.2 [June], pp.136-140. Available online also at: https://www.sciencedirect.com/science/article/pii/ $\underline{\text { S2213422017302834 [accessed in Ilorin, Nigeria: }}$ $5^{\text {th }}$ February 2019].

Marshall, Ellen. (2017). “The Statistics Tutor's Quick Guide to Commonly Used Statistical Tests". Available online at: http://www.statstutor.ac.uk/ resources/uploaded/tutorsquickguidetostatistics. pdf [accessed in Ilorin, Nigeria: $9^{\text {th }}$ June 2018].

Mjema, Mashauri Mwangasha. (2013). "The Causes and Management of Students' Unrest at the University of Arusha in Tanzania". Unpublished Ph.D. Thesis. Tanzania: The Open University of Tanzania. Available online also at: http://repository. out.ac.tz/766/1/Mjema $\mathrm{PhD}$ final research.pdf [accessed in Ilorin, Nigeria: $1^{\text {st }}$ June 2018].

NPE [National Policy of Education]. (2010). "Diversity of Cultural Expressions". Available online at: https://national.policy.of.education. cultural.expression [accessed in Ilorin, Nigeria: $25^{\text {th }}$ May 2018].

Odu, Onyike Margaret. (2013). "Management of Students' Crisis in Higher Institutions of Learning in Nigeria" in Mediterranean Journal of Social Sciences, Vol.4, No.8 [September], pp.91-97.

Okwakpam, Iheanyi N. \& Ikechi O. Okwakpam. (2012). "Causes and Levels of Truancy among Secondary School Students: A Case 
Study of Rivers State, Nigeria" in Problems of Education in the $21^{\text {st }}$ Century, Volume 45, pp.51-62. Available online also at: http://www. scientiasocialis.lt/pec/files/pdf/vol45/51-62. Okwakpam Vol.45.pdf [accessed in Ilorin, Nigeria: $9^{\text {th }}$ June 2018].

Olibie, Eyiuche Ifeoma, Gloria O. Eziuzo \& Chika Peace Enueme. (2013). "Inequalities in Nigerian Education Sector: Some Perspectives for Improvement" in IOSR Journal of Research \& Method in Education (IOSR-JRME), Vol.3, Iss.6 [November-December], pp.7-14. Available online also at: https://www.iosrjournals.org/iosr-jrme/ papers/Vol-3\%20Issue-6/B0360714.pdf?id=7221 [accessed in Ilorin, Nigeria: $15^{\text {th }}$ June 2018].

Oluwasanmi, B.V., O.L. Akande \& O.E. Taiwo. (2016). "Social Vices and the Effect of Cultism Activities among Students of Universities in Nigeria" in American Journal of Innovative Research and Applied Sciences, Volume 1(8), pp.336-346.

Omonijo, D.O. (2013). "Social Vices Associated with the Use of Information". Available online at: www.academic.journals.org $>$ article [accessed in Ilorin, Nigeria: $25^{\text {th }}$ May 2018].

Oni, Adesoji A. \& Jeremiah A. Adetoro. (2015). "The Effectiveness of Student Involvement in Decision Making and University Leadership: A Comparative Analysis of 12 Universities in South-West Nigeria" in Journal of Student Affairs in Africa, Volume 3(1), pp.65-81.

Orunbon, Nurudeen Olalekan et al. (2018). "Students' Crises and their Academic Performance in Lagos State Tertiary Institutions, Lagos State, Nigeria" in IJARET: International Journal of Advanced Research in Education \& Technology, Vol.5, Iss.1 [January-March], pp.712. Available online also at: http://ijaret.com/ wp-content/themes/felicity/issues/vol5issue1/ orunbon.pdf [accessed in Ilorin, Nigeria: $5^{\text {th }}$ February 2019].
Polit, Denise F. \& Cheryl Tatano Beck. (2010). "Generalization in Quantitative and Qualitative Research: Myths and Strategies" in International Journal of Nursing Studies, Volume 47, pp.14511458. Available online also at: https://core.ac.uk/ download/pdf/49282746.pdf [accessed in Ilorin, Nigeria: $9^{\text {th }}$ June 2018].

Saleh, Alam. (2013). "Relative Deprivation Theory, Nationalism, Ethnicity, and Identity Conflicts" in Geopolitics Quarterly, Vol.8, No.4 [Winter], pp.156-174. Available online also at: http://ensani.ir/file/download/ article/20130623093839-9617-60.pdf [accessed in Ilorin, Nigeria: $1^{\text {st }}$ June 2018].

Sileyew, Kassu Jilcha. (2019). "Research Design and Methodology" in IntechOpen, on August 7. DOI: 10.5772/intechopen.85731. Available online also at: https://www.intechopen.com/online-first/ research-design-and-methodology [accessed in Ilorin, Nigeria: $31^{\text {st }}$ August 2019].

Sulaiman, Kamal-Deen Olawale. (2016). "Religious Violence in Contemporary Nigeria: Implications and Options for Peace and Stability Order" in Journal for the Study of Religion, Vol.9, No.1. Available online also at: http://www. scielo.org.za/scielo.php?script=sci arttext\&pid $=$ S1011-76012016000100004 [accessed in Ilorin, Nigeria: 22 ${ }^{\text {nd }}$ June 2018].

Taiwo, B.M. (2012). “Students' Unrest in Nigerian Tertiary Institutions: Age and Sex as Determinants". Available online at: https:// kwcoelovin.edu.ng/publication [accessed in Ilorin, Nigeria: $25^{\text {th }}$ May 2018].

Williams, Carrie. (2007). "Research Methods" in Journal of Business \& Economic Research, Vol.5, No.3 [March], pp.65-72.

Yusuf, F.A. (2017). 'Students' Perception of Strike Actions on Academic Performance in Nigerian Universities". Unpublished Paper. Available and owned by the Author. 


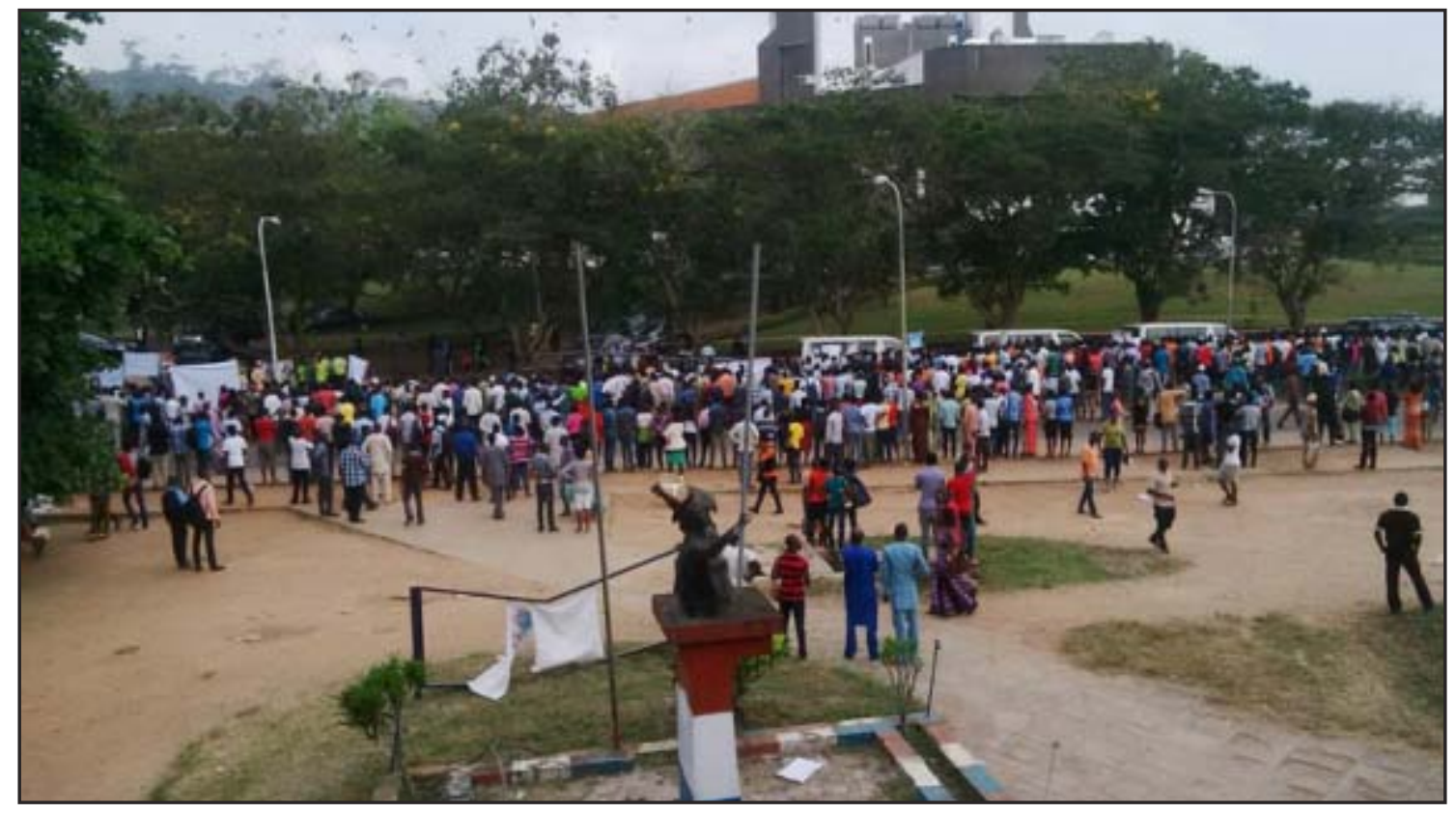

Students' Unrest in Nigerian Tertiary Institutions

(Source: http://www.nigerianeye.com, 22/6/2018)

The factors responsible for students' unrest in Nigerian tertiary institutions are: Unfavourable government policies; Poor staff-students' relationship; Poor teaching-learning facilities; High tuition fees; and Non-responsiveness of university authorities among others. No significant difference existed in the factors responsible for students' unrest in Nigerian tertiary institutions based on age, gender, and religion. 